\title{
Penerapan Balanced Scorecard untuk Menilai Kinerja Koperasi Karyawan Sekar Pusat Penelitian Kopi dan Kakao Indonesia di Kabupaten Jember
}

\author{
Endro Sugiartono $^{1^{*}}$, Zulfiah Naufalina ${ }^{2}$, Geri Barnas Saputra ${ }^{3}$ \\ ${ }^{1}$ Department of Agribusiness Management, Politeknik Negeri Jember \\ *endro@polije.ac.id
}

Submitted: 21 Feb 2021

Accepted: 24 May 2021

Published: 28 Jun 2021

\begin{abstract}
ABSTRAK
Penilaian kinerja dapat digunakan sebagai evaluasi dalam menentukan strategi yang tepat untuk meningkatkan kinerja pada koperasi. Dengan demikian, diperlukan alat pengukuran kinerja koperasi yang melihat dari sudut pandang keuangan dan non keuangan. Balanced Scorecard merupakan alat pengukuran kinerja yang dapat digunakan berdasarkan empat perspektif yaitu: perspektif keuangan, perspektif pelanggan, perspektif proses bisnis internal, dan perspektif pembelajaran dan pertumbuhan. Tujuan penelitian ini adalah untuk mengetahui kinerja Koperasi Karyawan SEKAR Pusat Penelitian Kopi dan Kakao Indonesia dengan menggunakan Balanced Scorecard yang dilihat dari keempat perspektif. Penelitian ini menggunakan metode deskriptif. Jenis data yang digunakan adalah data primer dan sekunder. Prosedur pengumpulan data yang digunakan adalah wawancara, observasi, dan kuesioner. Hasil penelitian penilaian kinerja Koperasi Karyawan SEKAR Pusat Penelitian Kopi dan Kakao Indonesia pada tahun 2012-2015 dengan menggunakan penerapan konsep Balanced Scorecard berdasarkan perspektif keuangan dengan indikator pertumbuhan pendapatan penjualan, pertumbuhan pendapatan jasa, dan sisa hasil usaha (SHU) dalam kondisi sangat sehat, pada perspektif pelanggan dengan indikator akuisisi anggota dan retensi anggota dalam kondisi sangat sehat, pada perspektif proses bisnis internal dengan indikator kerjasama baru dan layanan usaha baru dalam kondisi kurang sehat, pada perspektif pembelajaran dan pertumbuhan dengan indikator retensi karyawan koperasi dan produktivitas karyawan koperasi dalam kondisi sangat sehat
\end{abstract}

Kata kunci: Motivasi, Kompensasi, Lingkungan Kerja, Produktivitas

\begin{abstract}
Performance assessment can be used as evaluation to determine a good strategic to improve the cooperative performance. Therefore, this cooperative needed a performance measurement tool to look at the financial and non-financial perspective. Balanced Scorecard is a performance measurement tool that can be used by four perspectives: financial perspective, customer perspective, internal business processes perspective, and learning and growth perspective. The purpose of this research is to know about the performance of SEKAR employee cooperative Indonesian coffee and cocoa research institute with used Balanced Scorecard based on four perspectives. This research used descriptive method. The type of data that used are primary and secondary data. Data collection procedures used interview, observation, and questionnaire. The result of performance assessment research at SEKAR employee cooperative Indonesian Coffee and Cocoa Research Institute in 2012-2015 using the application of Balanced Scorecard concept is based on the financial perspective with indicators of sales income growth, service income groeth, and net profit margin (SHU) in a very healthy condition, customer perspective with indicators of acquisition of mamber and mamber retention in a very healthy condition, Internal business process perspective with indicators of new cooperation and new service business in a unhealthy condition, learning and growth perspective with indicators of employees cooperative retention and employees cooperative productivity in very healthy condition.
\end{abstract}

Keyword: Motivation, Compensation, Work Environment, Productivity 


\section{Pendahuluan}

Indonesia sebagai negara berkembang berada pada kondisi perekonomian dengan tingkat persaingan yang kompetitif untuk terus meningkatkan taraf perekonomiannya. Dimana, didalamnya seluruh bentuk badan usaha pada sektor bisnis yang terdapat diIndonesia turut serta sebagai pelaku utama yang berperan penting dalam upaya peningkatan taraf perekonomian bangsa ini.

Saat ini di Indonesia mengenal 3 bentuk badan usaha yang meliputi Badan Usaha Milik Negara (BUMN), Badan Usaha Milik Swasta (BUMS), maupun Koperasi. Ketiga bentuk badan usaha ini baik yang dikelola oleh pihak pemerintah maupun yang dikelola oleh pihak swasta dan juga koperasi dituntut untuk berlomba-lomba dalam meningkatkan kinerja perusahaannya.

Namun dalam fenomena bisnis yang terjadi di negara ini, BUMN dan BUMS lah yang mendominasi dalam persaingan dunia bisnis, sedangkan keterlibatan koperasi dianggap kurang berkontribusi dalam persaingan tersebut. Padahal bila menilik kembali pada UUD 1945. Negara Indonesia memiliki pandangan yang khusus tentang perekonomiannya. Hal ini termuat dalam UUD 1945, Bab XIV Pasal 33 ayat (1) yang menyebutkan bahwa "Perekonomian disusun sebagai usaha bersama berdasar atas azas kekeluargaan."

Seiring dengan tuntutan dunia usaha yang semakin kompleks, koperasi diharapkan dapat menempatkan diri sebagai salah satu kekuatan ekonomi yang sejajar dengan kekuatan ekonomi lain yang ada. sehingga dengan kata lain koperasi juga harus mampu bangkit dan sejajar dengan BUMN dan BUMS. Dengan cara terus meningkatkan kinerjanya dari segala aspek. Oleh karena itu untuk mengetahui tingkat perkembangan kinerjanya pihak manajemen koperasi yang dalam hal ini adalah pengurus koperasi perlu melakukan pengukuran kinerja yang bertujuan sebagai bentuk evaluasi kinerja dari koperasi tersebut.

Pengukuran kinerja merupakan tindakan pengukuran yang di lakukan terhadap berbagai aktivitas dalam rantai nilai yang ada pada suatu perusahaan (Yuwono, 2006). Kecenderungan yang dilakukan oleh badan usaha- badan usaha pada umumnya dalam mengukur kinerjanya masih berfokus pada aspek keuangan saja tanpa terlalu memperhatikan aspek-aspek lain diluar aspek keuangan (non keuangan), karena memang pada dasarnya tidak dapat dipungkiri bahwa aspek keuangan yang merupakan salah satu aspek internal perusahaan berkaitan langsung dengan untung ruginya suatu perusahaan. Sehingga dalam hal ini bagi pihak manajemen pengukuran kinerja keuangan dianggap sebagai aspek terpenting yang paling berpengaruh pada siklus hidup perusahaan. Padahal aspek-aspek non keuangan sebagai aspek dari eksternal juga sangat penting untuk dievaluasi dan dijadikan pertimbangan dalam proses penentuan kebijakan dan strategi jangka panjang untuk mampu terus bersaing dengan perusahaan kompetitor.

Dewasa ini, semakin disadari bahwa pengukuran kinerja keuangan yang digunakan oleh banyak perusahaan untuk mengukur kinerja tidak lagi memadai, sehingga dikembangkan suatu konsep Balanced Scorecard yang diperkenalkan oleh Robert S. Kaplan dan David P. Norton yang mampu mengukur kinerja perusahaan secara keseluruhan. Konsep ini menyeimbangkan pengukuran atas kinerja suatu unit bisnis antara kinerja keuangan dan juga non keuangan yang selama ini dianggap lebih menekankan pada pengukuran kinerja keuangan saja.

Balanced Scorecard merupakan suatu sistem manajemen, pengukuran, dan pengendallian yang secara cepat, tepat, komprehensif dapat memberikan pemahaman kepada manajer tentang performance bisnis. Pengukuran kinerja tersebut memandang unit bisnis dari empat perspektif, yaitu perspektif keuangan, pelanggan, proses bisnis internal perusahaan, serta proses pembelajaran dan pertumbuhan. Penilaian 4 perspektif ini, diawali dengan penentuan beberapa indikator yang perlu memperhatikan aspek tertentu, yang meliputi kondisi internal dan eksternal perusahaan pada periode waktu dimasa lalu, masa kini dan masa yang akan datang (Yuwono, 2006).

Di wilayah Kabupaten Jember telah didirikan 1.822 koperasi yang beranggotakan 81.805 orang (BPS, 2014). Salah satunya adalah Koperasi Karyawan SEKAR sebagai jenis koperasi serba usaha yang berada dibawah 
naungan Pusat Penelitian Kopi dan Kakao Indonesia yang belokasikan di Jember. Dalam perjalanan perkoperasiannya, Koperasi Karyawan SEKAR pada tahun 2015 memiliki jumlah anggota sebanyak 350 anggota yang merupakan seluruh karyawan Pusat Penelitian Kopi dan Kakao Indonesia. Selain itu, dalam pengambangan sektor usaha Koperasi Karyawan SEKAR telah mengelolah dan menjalankan sebanyak 7 unit usaha, di antaranya: Unit pertokoan, unit tiketing, unit fotocopy, unit kerjasama, unit jasa pembayaran macam-macam rekening, unit simpan pinjam, dan unit kantin. Dari 7 unit usaha tersebuut, Kontribusi terbesar terhadap pendapatan yang koperasi ini dari tahun ke tahun diperoleh dari kontribusi pendapatan unit usaha pertokoan.

Meskipun demikian, dalam pelaksanaan kegiatan usahanya koperasi ini belum pernah melaksanakan evaluasi penilaian kinerja dengan menggunakan konsep Balanced Scorecard pada bidang usahanya.

Berdasarkan hal tersebut, Koperasi Karyawan SEKAR Pusat Penelitian Kopi dan Kakao Indonesia memerlukan pengukuran kinerja baik dari segi keuangan maupun non keuangan agar dapat membantu pihak pengelolah manajemen koperasi ini dalam mengevaluasi dan meningkatkan kinerjanya dengan menggunakan konsep Balanced Scorecard, sehingga diharapkan Koperasi ini dapat lebih jelas dalam mengimplementsikan strategi yang akan digunakan untuk mencapai target kinerja yang telah ditetapkan. Dengan adanya dasar tersebut, maka penelitian ini mengambil judul "Penerapan Balanced Scorecard Untuk Menilai Kinerja Koperasi Karyawan SEKAR Pusat Penelitian Kopi dan Kakao Indonesia di Kabupaten Jember".

\section{Metode Penelitian}

Penelitian ini dilakukan untuk menjelaskan kinerja Koperasi Karyawan SEKAR Pusat Penelitian Kopi dan Kakao Indonesia dengan menggunakan konsep Balanced Scorecard. Penelitian ini termasuk dalam penelitian survey yang bertujuan untuk memperoleh data yang berhubungan dengan objek penelitian dan penelitian deskriptif yang digunakan untuk menganalisis data yang diperoleh dari pernelitian survey.

\subsection{Populasi Penelitian}

Subjek penelitian yang diteliti adalah Koperasi Karyawan SEKAR Pusat Penelitian Kopi dan Kakao Indonesia, termasuk didalamnya jumlah produk yang ditawarkan, proses layanan produk dan hal lain yang berhubungan dengan perusahaan, karyawan yang bersangkutan untuk mengukur tingkat kepuasan karyawan, serta halhal berhubungan dengan pelanggan terkait dengan tingkat kepuasan pelanggan. Pelanggan yang dimaksud dalam hal ini merupakan anggota dari koperasi ini.

\subsection{Teknik pengambilan sampel}

Penelitian ini merupakan penelitian sensus karena melibatkan seluruh populasi yang ada. Populasi yang dimaksud yaitu keseluruhan aspek yang terdapat pada Koperasi Karyawan SEKAR Pusat Penelitian Kopi dan Kakao Indonesia.

\subsection{Klasifikasi Variabel}

Penyusunan indikator kinerja (variabel) dimaksudkan untuk memudahkan dan membatasi penelitian yang akan dilaksanakan. Indikator kinerja yang digunakan dalam penelitian adalah sebagai berikut

\begin{tabular}{|c|c|c|}
\hline & Kategori & Indikator \\
\hline 1. & Keuangan & $\begin{array}{ll}\text { a. } & \text { Pertumbuhan } \\
\text { b. } & \text { Pendapatan Penjualan } \\
\text { c. } & \text { Pertumbuhan } \\
& \text { Pendapatan Jasa } \\
& \text { Sisa Hasil Usaha (SHU) }\end{array}$ \\
\hline 2. & Pelanggan & $\begin{array}{l}\text { a. Akuisisi Anggota } \\
\text { b. Retensi Anggota }\end{array}$ \\
\hline 3. & $\begin{array}{l}\text { Proses Bisnis } \\
\text { Internal }\end{array}$ & $\begin{array}{ll}\text { a. } & \text { Kerjasama Baru } \\
\text { b. Layanan Usaha Baru }\end{array}$ \\
\hline 4. & $\begin{array}{l}\text { Pembelajaran dan } \\
\text { Pertumbuhan }\end{array}$ & $\begin{array}{l}\text { a. Retensi Karyawan } \\
\text { b. Koperasi } \\
\text { Produktivitas Karyaw an } \\
\text { Koperasi }\end{array}$ \\
\hline
\end{tabular}

\subsection{Definisi Operasional Variabel}

\subsubsection{Perspektif Keuangan}

Penilaian kinerja keuangan perusahaan berhubungan dengan pengukuran profitabilitas. Pada perspektif keuangan pengukuran yang 
digunakan untuk mengukur kinerja keuangan adalah :

a. Pertumbuhan Pendapatan Penjualan

Rasio Petumbuhan pendapatan penjualan diperoleh dari pendapatan unit usaha penjualan saat ini dikurangi dengan pendapatan unit usaha penjualan tahun sebelumnya, lalu dibandingkan dengan keseluruhan pendapatan tiap-tiap periode.

\section{b. Pertumbuhan Pendapatan Jasa}

Rasio Pertumbuhan pendapatan jasa diperoleh dari pendapatan unit usaha pelayanan jasa saat ini dikurangi dengan pendapatan unit usaha pelayanan jasa tahun sebelumnya, lalu dibandingkan dengan keseluruhan pendapatan tiap-tiap periode.

\section{c. Sisa Hasil Usaha (SHU)}

Rasio Sisa Hasil Usaha (SHU) terhadap pendapatan merupakan yang paling penting, karena mampu menggambarkan kesuksesan dari suatu perusahaan dalam memperoleh laba usaha.

\subsubsection{Perspektif Pelanggan}

Pengukuran kinerja pada perspektif ini dilakukan untuk mengetahui tingkat kesetiaan pelanggan terhadap perusahaan dan kemampuan perusahaan dalam menarik pelanggan baru. Pelanggan yang dimaksudkan dalam penelitian ini adalah seluruh anggota Koperasi Karyawan SEKAR. Adapun ukuran yang digunakan adalah

\section{a. Akuisisi Anggota}

Mengukur tingkat dimana suatu koperasi mampu menarik dan merekrut anggota baru, yang dalam hal ini merupakan pelanggan utama dari koperasi tersebut.

\section{b. Retensi Anggota}

Mengukur tingkat dimana koperasi dapat mempertahankan hubungan dengan anggota dan mnegukur sejauh mana keberhasilan koperasi dalam mempertahankan loyalitas anggotanya.

\subsubsection{Perspektif Proses Bisnis Internal}

Proses bisnis internal merupakan suatu proses bisnis yang dilakukan perusahaan untuk memperoleh hasil finansial dalam mengembangkan bisnisnya. Pengukuran kinerja pada perspektif ini dilakukan untuk mengetahui tingkat Bisnis Internal yang dilakukan oleh perusahaan.Adapun ukuran yang digunakan adalah sebagai berikut :

a. Kerjasama Baru

Pengukuran indikator kerjasama baru dalam hal ini merupakan pengukuran tingkat kemampuan koperasi dalam mengembangkan kerjasama-kerjasama baru dalam bentuk kemitraan.

b. Layanan Usaha Baru

Layanan Usaha Baru yang dimaksud dalam hal ini merupakan pengukuran tingkat kemampuan koperasi dalam melakukan ekspansi terhadap bisnisnya dengan mengembangkan bentuk layanan usaha baru dari ketujuh unit usahanya.

\subsubsection{Perspektif Pembelajaran dan Pertumbuhan}

Persektif pembelajaran dan pertumbuhan merupakan usaha yang dilakukan perusahaan dalam mengembangkan perusahaan melalui pembelajaran dan pelatihan kepada karyawan. Adapun pengukurannya sebagai berikut :

a. Retensi karyawan koperasi

Pengukuran untuk melihat seberapa jauh koperasi ini mampu mempertahankan loyalitas karyawan koperasi yang dimiliki.

b. Produktivitas karyawan koperasi

Pengukuran untuk melihat lebih sejauh mana kemampuan tenaga kerja dalam menyelesaikan tugas yang diberikan. Pengukuran produktivitas karyawan dapat dilakukan dengan mengidentifikasi seberapa besar pendapatan yang dihasilkan dari masing-masing karyawan setiap periodenya.

\subsection{Instrumen Penelitian}

Instrumen penelitian adalah suatu alat yang digunakan mengukur fenomena alam maupun sosial yang diamati. Secara spesifik semua fenomena ini disebut variabel penelitian. Variabel-variabel tersebut diberikan definisi operasionalnya, dan selanjutnya ditentukan indikator yang akan diukur. Dari indikator ini kemudian dijabarkan menjadi butur-butir pertanyaan atau pernyataan. Penelitian yang 
digunakan merupakan analisis kuantitatif dan kualitatif.

\subsection{Lokasi Penelitian}

Lokasi kegiatan penelitian akan dilakukan di Koperasi Karyawan SEKAR Pusat Penelitian Kopi dan Kakao Indonesia yang ada di JL. PB. Sudirman 90, Jember dan JL. Renteng 23, Jenggawah, Jember . Lokasi tersebut dipilih dengan pertimbangan - pertimbangan karena koperasi tersebut berpotensi untuk lebih dikembangkan dan ditingkatkan lagi kinerjanya.

\subsection{Prosedur Pengumpulan Data}

\subsubsection{Sumber Data}

Jenis data yang digunakan dalam penelitian ini adalah data primer dan data sekunder yang dimiliki oleh Koperasi Karyawan SEKAR Pusat Penelitian Kopi dan Kakao Indoneia.

\subsubsection{Prosedur Pengumpulan Data}

Prosedur pengumpulan data merupakan langkah yang paling strategis dalam penelitian, karena tujuan utama dari penelitian ini adalah mendapatkan data. Tanpa mengetahui teknik pengumpulan data, maka peneliti tidak akan mendapatkan data yang memenuhi standar data yang ditetapkan, (Sugiyono, 2013:156). Prosedur pengumpulan data yang digunakan dalam penelitian ini adalah :
a. Kuesioner
b. Wawancara
c. Dokumentasi.

\subsection{Analisis SWOT}

Rangkuti (2009:18) mengungkapkan bahwa Analisis SWOT adalah identifikasi berbagai faktor secara sistematis untuk merumuskan strategi perusahaan.. faktor tersebut terdiri dari faktor eksternal dan faktor internal.

\subsubsection{Pengukuran Balanced Scorecard}

a. Pengukuran Kinerja Perspektif Keuangan

- Pertumbuhan Pendapatan Penjualan =

Pendapatan penjualan tahun $\mathrm{t}$ - Pendapatan penjualan (t-1) Pendapatan Penjualan tahun( $\mathrm{t}-1)$
- Pertumbuhan pendapatan Jasa = $\frac{\text { Pendapatan Jasa tahun } \mathrm{t}-\text { Pendapatan Jasa }(\mathrm{t}-1)}{\text { Pendapatan Jasa }(\mathrm{t}-1)} \times 100 \%$

- Sisa Hasil Usaha (SHU) = SHU Pendapatan Bersih

b. Pengukkuran Kinerja Perspektif Pelanggan

- Akuisisi Anggota = $\frac{\text { Jumlah Anggota Baru Th. t }}{\text { Jumlah Seluruh Anggota Th. t }} \times 100 \%$

- Retensi Anggota = JumlahAnggotayangbertahan Jumlah seluruh Anggota

$\times 100 \%$

c. Pengukuran Kinerja Perspektif Proses Bisnis Internal

- Kerjasama Baru= =

$$
\begin{aligned}
& \frac{\text { Jumlah Kerjasama baru }}{\text { Jumlah Kerjasama keseluruhan }} \times 100 \% \\
& \text { - Layanan Usaha Baru = } \\
& \text { Jumlah Layanan Usaha baru } \\
& \text { Jumlah Layanan Usaha keseluruhan }
\end{aligned}
$$

d. Pengukuran Kinerja Perspektif Pembelajaran dan Pertumbuhan

\section{- Retensi Karyawan Koperasi =}

$\frac{\text { JumlahKaryawanyangbertahanTh.t }}{\text { Jumlah Seluruh Karyawan Th. t }} \times 100 \%$

- Produktivitas Karyawan Koperasi = Pendapatan Jumlah Karyawan

\subsubsection{Key Perfomance Indicators (KPI)}

Key Performance Indicator (KPI) merupakan tolok ukur finansial dan non finansial yang digunakan untuk membantu perusahaan dalam menilai kemajuan terhadap sasaran perusahaan. 
Table 1. Key Performance Indicator (KPI)

\begin{tabular}{|c|c|c|c|c|c|}
\hline Perspektif & $\begin{array}{l}\text { Tujuan } \\
\text { Strategis } \\
\end{array}$ & $\begin{array}{l}\text { Key Performance } \\
\text { Indicators }\end{array}$ & Parameter & Aktual & Target \\
\hline Keuangan & & $\begin{array}{l}\text { Pertumbuhan } \\
\text { pendapatan penjualan } \\
\text { Pertumbuhan } \\
\text { Pendapatan Jasa } \\
\text { Sisa Hasil Usaha } \\
\text { (SHU) } \\
\end{array}$ & $\begin{array}{l}\% \text { Pertumbuhan } \\
\text { pendapatan penjualan } \\
\% \text { Pertumbuhan } \\
\text { Pendapatan Jasa } \\
\% \text { perolehan SHU }\end{array}$ & & \\
\hline Pelanggan & & $\begin{array}{l}\text { Akuisi Anggota } \\
\text { Retensi Anggota }\end{array}$ & $\begin{array}{l}\text { \% Jumlah anggota baru } \\
\% \text { Jumlah anggota yang } \\
\text { bertahan }\end{array}$ & & \\
\hline $\begin{array}{l}\text { Proses Bisnis } \\
\text { Internal }\end{array}$ & & $\begin{array}{l}\text { Kerjasama Baru } \\
\text { Layanan Usaha Baru }\end{array}$ & $\begin{array}{l}\text { \% Jumlah kerjasama } \\
\text { baru } \\
\text { \% Jumlah layanan Usaha } \\
\text { Baru }\end{array}$ & & \\
\hline $\begin{array}{l}\text { Pembelajaran dan } \\
\text { Pertumbuhan }\end{array}$ & & $\begin{array}{l}\text { Retensi Karyawan } \\
\text { Koperasi } \\
\text { Produktivitas } \\
\text { karyawankoperasi } \\
\end{array}$ & $\begin{array}{l}\text { \% Jumlah karyawan } \\
\text { yang bertahan } \\
\text { Jumlah pendapatan yang } \\
\text { dihasilkankaryawan }\end{array}$ & & \\
\hline
\end{tabular}

\subsection{Pengukuran Target Kinerja dalam Balanced Scorecard}

\section{Hasil Dan Pembahasan}

Berdasarkan Matriks SWOT, posisi

Salah satu acuan untuk menetapkan target kinerja kepada masa yang akan datang adalah menggunakan kinerja masa lalu. Kecenderungan masa lalu dapat dikembangkan untuk peningkatan kinerja dimasa yang akan datang. Tujuan-tujuan strategis dapat juga menjadi pendorong untuk mencapai target dimasa yang akan datang. Penetapan target berdasarkan tujuan strategis dapat dikembangkan sebagai berikut (Rangkuti, 2013):

Hasil total kinerja yang diperoleh dari pengukuran kinerja Balanced Scorecard dapat dilihat kondisi kinerjanya berdasarkan kriteria totalkinerja sebagaiberikut

\begin{tabular}{|c|c|c|}
\hline \multirow{3}{*}{ SangatSehat } & $\overline{A A A}$ & $>05$ \\
\hline & $\mathrm{AA}$ & $80<\mathrm{TS}<95$ \\
\hline & A & $65<\mathrm{TS}<80$ \\
\hline \multirow[t]{3}{*}{ KurangSehat } & BBB & $50<\mathrm{TS}<65$ \\
\hline & $\mathrm{BB}$ & $40<\mathrm{TS}<50$ \\
\hline & B & $30<\mathrm{TS}<40$ \\
\hline \multirow[t]{3}{*}{ TidakSehat } & $\mathrm{CCC}$ & $20<\mathrm{TS}<30$ \\
\hline & $\mathrm{CC}$ & $10<\mathrm{TS}<20$ \\
\hline & $\mathrm{C}$ & $\mathrm{TS}<10$ \\
\hline
\end{tabular}

Koperasi Karyawan SEKAR berada pada Kuadran I, yang artinya pada posisi ini Koperasi Karyawan SEKAR dapat mengembangkan Strategi Agresif dalam pengembangan usahanya, yaitu dengan menggunakan kekuatan yang dimiliki untuk merebut dan memanfaatkan peluang yang sebesar-besarnya.

\subsection{Pengukuran Kinerja Berdasarkan Balanced Scorecard}

Table 2. Perspektif Keuangan

\begin{tabular}{lllll}
\hline Indikator & Tahun & & \\
\cline { 2 - 4 } & $\mathbf{2 0 1 2}$ & $\mathbf{2 0 1 3}$ & $\mathbf{2 0 1 4}$ & $\mathbf{2 0 1 5}$ \\
\hline $\begin{array}{l}\text { Pertumbuhan } \\
\text { Pendapatan } \\
\text { Penjualan }\end{array}$ & $32,9 \%$ & $-15,7 \%$ & $-6,3 \%$ & $23,6 \%$ \\
\hline $\begin{array}{l}\text { Pertumbuhan } \\
\text { Pendapatan Jasa }\end{array}$ & $12,9 \%$ & $21,7 \%$ & $25 \%$ & $19,5 \%$ \\
& & & \\
\hline $\begin{array}{l}\text { Sisa Hasil Usaha } \\
\text { (SHJumber: Lampiran 2.1 }\end{array}$ & $\begin{array}{c}\text { Perhitungan Empat Perspektif } \\
\text { Balanced Scorecard }\end{array}$ \\
\hline
\end{tabular}


Table 3. Perspektif Pelanggan

\begin{tabular}{|c|c|c|c|c|}
\hline \multirow[b]{2}{*}{ Indikator } & \multicolumn{3}{|c|}{ Tahun } & \multirow[b]{2}{*}{2015} \\
\hline & 2012 & 2013 & 2014 & \\
\hline $\begin{array}{l}\text { Akuisis } \\
\text { Anggota }\end{array}$ & $0,5 \%$ & $2,3 \%$ & $1,3 \%$ & $1,4 \%$ \\
\hline $\begin{array}{l}\text { Retensi } \\
\text { Anggota }\end{array}$ & $99 \%$ & $99,74 \%$ & $99,48 \%$ & $90,91 \%$ \\
\hline
\end{tabular}

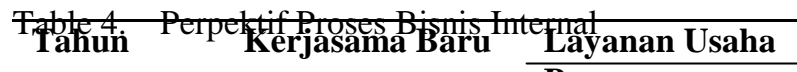

\begin{tabular}{|c|c|c|}
\hline & & Baru \\
\hline 2012 & $40 \%$ & $0 \%$ \\
\hline 2013 & $25 \%$ & $0 \%$ \\
\hline 2014 & $25 \%$ & $0 \%$ \\
\hline 2015 & $20 \%$ & $0 \%$ \\
\hline
\end{tabular}

Balanced Scorecard

\begin{tabular}{|c|c|c|}
\hline $\begin{array}{l}\text { Table 5. } \\
\text { Tahun }\end{array}$ & $\begin{array}{l}\text { Retensi } \\
\text { Karyawan } \\
\text { Koperasi } \\
\end{array}$ & $\begin{array}{l}\text { Produktivitas } \\
\text { Karyawan (Rp/Tahun) }\end{array}$ \\
\hline 2012 & $100 \%$ & Rp 720.754 .789 \\
\hline 2013 & $100 \%$ & Rp 584.414.649 \\
\hline 2014 & $100 \%$ & Rp 579.846.741 \\
\hline 2015 & $90,91 \%$ & Rp 782.065.991 \\
\hline
\end{tabular}

Balanced Scorecard
Hasil pengukuran kinerja Koperasi Karyawan SEKAR Pusat Penelitian Kopi dan Kakao Indonesia menggunakan Balanced Scorecard sebagai tolak ukur secara keseluruhan adalah sebagai berikut

\begin{tabular}{|c|c|c|c|}
\hline Perspektif & $\begin{array}{l}\text { Total } \\
\text { Kineria }\end{array}$ & Kategori & $\begin{array}{l}\text { Kondisi } \\
\text { Kineria }\end{array}$ \\
\hline Keuangan & 82,5 & AA & $\begin{array}{l}\text { Sangat } \\
\text { Sehat }\end{array}$ \\
\hline Pelanggan & 82,9 & AA & $\begin{array}{l}\text { Sangat } \\
\text { Sehat }\end{array}$ \\
\hline Bisnis Internal & 45,8 & BB & $\begin{array}{l}\text { Kurang } \\
\text { Sehat }\end{array}$ \\
\hline $\begin{array}{l}\text { Pembelajaran } \\
\text { dan Pertúnbbahan }\end{array}$ & $\begin{array}{l}97,6 \\
\text { Data olah }\end{array}$ & $\begin{array}{l}\text { AAA } \\
\text { Lampiran }\end{array}$ & $\frac{\text { Sangat }}{B \text { Sehartarka }}$ \\
\hline
\end{tabular}

\begin{tabular}{llll}
\hline Tahun & Kinerja & Kategori & Kondisi Kinerja \\
& & & Sangat Sehat \\
2012 & 75,9 & A & Sangat Sehat \\
2013 & 78,6 & A & Sangat Sehat \\
2014 & 74,6 & A & Sangat Sehat \\
2015 & 79,8 & A & Sangat Sehat \\
Total & $\mathbf{7 7 , 2}$ & A & Pengukuran Kinerja
\end{tabular}

Table 6. Analisis SWOT IFAS pada Koperasi Karyawan SEKAR

\begin{tabular}{llll}
\hline No & Item Kekuatan & Bobot & Rating \\
\hline 1 & Peningkatan pendapatan jasa & 0,12 & 4 \\
\hline 2 & Peningkatan perolehan SHU & 0,12 & 4 \\
\hline 3 & Kemudahan dalam bertransaksi & 0,10 & 3 \\
\hline 4 & Pelayanan keemitraan yang prima & 0,10 & 3 \\
\hline 5 & Karyawan memiliki katerampilan bekerja sesuai dengan bidangnya & 0,09 & 4 \\
\hline 6 & Loyalitas karyawan & 0,09 & 3 \\
\hline No & Item Kelemahan & 0,62 & \\
\hline 1 & Penurunan pertumbuhan pendapatan penjualan & Bobot & Rating \\
\hline 2 & Lokasi kurang strategis & 0,11 & 2 \\
\hline 3 & Promosi kurang dapat menarik konsumen luar & 0,10 & 2 \\
\hline 4 & Belum ada SOP tertulis bagi karyawan & 0,09 & 1 \\
\hline & Jumlah Kelemahan & 0,08 & 2 \\
\hline & Jumlah Bobot Faktor Strategi Internal & 0,38 & \\
\hline
\end{tabular}

\begin{tabular}{l} 
Skor \\
\hline \hline 0,48 \\
\hline 0,48 \\
\hline 0,30 \\
\hline 0,30 \\
\hline 0,36 \\
\hline 0,27 \\
\hline 2,19 \\
\hline Skor \\
\hline 0,22 \\
\hline 0,20 \\
\hline 0,09 \\
\hline 0,16 \\
\hline 0,67 \\
\hline
\end{tabular}


Table 7. Analisis SWOT EFAS pada Koperasi Karyawan SEKAR

\begin{tabular}{llllll}
\hline No & Item Peluang & Bobot & Rating & Skor \\
\hline 1 & Masih terbukanya potensi pengembangan layanan usaha baru. & 0,15 & 4 & 0,60 \\
\hline 2 & Target Pasar lebih terfokus & 0,14 & 3 & 0,42 \\
\hline 3 & Luasnya potensi pengembangan Kerjasama Kemitraan & 0,12 & 4 & 0,48 \\
\hline 4 & Besarnya kesempatan mengikuti Diklat dari Dinas Koperasi dan UMKM Jember & 0,11 & 3 & 0,33 \\
\hline No & Item Ancaman & 0,52 & Bobot & Rating & Skor \\
\hline 1 & Putusnya hubungan kerjasama dengan mitra & 0,28 \\
\hline 2 & Daya beli anggota/pelanggan yang rendah & 0,14 & 2 \\
\hline 3 & Banyaknya pesaing yang lebih mudah dijangkau oleh pelanggan & 0,12 & 2 \\
\hline 4 & Kondisi ekonomi & 0,11 & 2 & 0,24 \\
\hline & Jumlah Ancaman & 0,11 & 1 \\
\hline & Jumlah Bobot Faktor Strategi Eksternal & 0,48 & 0,22 \\
\hline
\end{tabular}

\subsection{Key Performance Indicator (KPI)}

\begin{tabular}{lll}
\hline $\begin{array}{l}\text { Tujuan } \\
\text { Perspektif Kewangan }\end{array}$ & Sasaran Strategik & KPI (Key Performance Indicator) \\
Meningkatkan pendapatan & Mengoptimalkan pendapatan barang & Pertumbuhan Pendapatan Penjualan \\
Meningkatkan perolehan SHU & $\begin{array}{l}\text { dan jasa untuk meningkatkan } \\
\text { pendapatan dan perolehan SHU }\end{array}$ & $\begin{array}{l}\text { Pertumbuhan Pendapatam Jasa } \\
\text { Sisa Hasil Usaha (SHU) }\end{array}$
\end{tabular}

\section{Perspektif Pelanggan}

Meningkatkan loyalitas anggota

Meningkatkan jumlah anggota baru Menjaga hubungan baik dengan
anggota dan memenangkan anggota
baru

Mengembangkan Ekspansi Usaha dengan mengoptimalkan fungsi pelayanan pada anggota dan menjalin hubungan baik dengan mitra untuk pengembangan bentuk kerjasamakerjasama baru.

\section{Akuisisi Anggota \\ Retensi Anggota}

Kerjasama Baru

Layanan Usaha Baru

\section{Perspektif Pembelajaran dan Pertumbuhan}

Meningkatkan loyalitas karyawan

Peningkatan produktivitas karyawan
Menciptakan lingkungan kerja yang nyaman serta memberikan pelatihan untuk memotivasi peningkatan kinerja karyawan.
Retesi Karyawan Koperasi

Produktivitas Karyawan Koperasi 


\section{Kesimpulan}

Berdasarkan hasil pengukuran kinerja Koperasi Karyawan SEKAR dapat ditarik kesimpulan antara lain:

a. Pengukuran kinerja berdasarkan kondisi faktor internal dan faktor eksternal yang mempengaruhi kegiatan operasional Koperasi Karyawan SEKAR yaitu:

b. Berdasarkan analisis SWOT didapatkan hasil bahwa pada Koperasi Karyawan SEKAR. Berdasarkan hasil perhitungan dan Analisis pembahasan yang telah dilakukakan mengunakaan balanced scorecard, maka dapat disimpulkan bahwa :

- Perspektif Keuangan

Pada perspektif keuangan, KPI yang digunakan pertumbuhan pendapatan penjualan, pertumbuhan pendapatn jasa, kinerja Koperasi Karyawan SEKAR berdasarkan perspektif keuangan dalam kondisi yang sangat sehat dan dalam tahap pertumbuhan dengan total kinerja sebesar $82,5 \%$.

- Perspektif Pelanggan

Pada perspektif pelanggan dengan total kinerja sebesar 82,9\% . Kondisi ini menandakan Koperasi ini mampu memberikan menjaga hubungan baik dengan anggota dan memenangkan anggota baru sehingga dapat meningkatkan loyalitas anggota dan meningkatkan jumlah anggota baru.

- Perspektif Proses Bisnis Internal

Pada perspektif kinerja Koperasi Karyawan SEKAR dalam kondisi kurang sehat. Dengan total kinerja pada perspektif proses bisnis internal sebasar 45,8\%. Kondisi ini menandakan bahwa koperasi ini belum dapat memanfaatkan potensi yang dimiliki dari anggota dan juga mitranya

- Perspektif pertumbuhan

Pada perspektif pertumbuhan dan pembelajaran bahwa kondisi kinerja Koperasi Karyawan SEKAR pada perspektif ini dalam kondisi sangat baik. Dengan total kinerja sebesar 97,6\%. Kondisi ini menandakan bahwa koperasi ini mampu menjaga loyalitas karyawan dengan memperhatikan kesejahteraan karyawannya.

\section{Daftar Pustaka}

[1] Erlina. 2009. “Analisis Kinerja Perusahaan dengan Metode Balanced Scorecard (BSC) dan SWOT". Jurnal Penelitian Ilmu Teknik. UPN "Veteran". Jawa Timur. Vol. 9. No.1. ISSN.

[2] Gaspersz, V. 2005. Sistem Manajemen Kinerja Terintegrasi Balanced Scorecard Dengan Six Sigma Untuk Organisasi Pemerintah. Jakarta: PT. Gramedia Pustaka Utama.

[3] Husen. S. 2010. "Penerapan Balanced Scorecard Untuk Kepuasan Pelanggan dan Pegawai pada Balai Besar Kemasan dan Kimia (BBKK).” Jurnal Manajemen dan Kewirausahaan. Sekolah Tinggi Ilmu Ekonomi Swadaya. Jakarta. Vol.12, No 1. ISSN: 1411-1438.

[4] Indranatha, I., I.K Suryanawa. 2013. "Pengukuran Kinerja Berbasis Balanced Scorecard Pada Koperasi Serba Usaha Kuta Mimba." Jurnal Akuntansi. Universitas Udayana. Bali. Vol. 4. No. 3. ISSN: 2302-8556.

[5] Kuncoro, M. 2005. Strategi: Bagaimana Meraih Keunggulan Kompetitif?. Jakarta: Erlangga, Jakarta.

[6] Mulyadi. 2001. Balanced Scorecard; Alat Manajemen Kontemporer Untuk Pelipatgandakan Kinerja Laporan Keuangan Perusahaan, Cetakan Kesatu, Jakarta: Salamba Empat.

[7] Putrayasa. I. 2011. "Pengukuran Kinerja Ditinjau Dari Empat Perspektif Balanced Scorecard Pada Koperasi Mertha Yasa Di Desa Penarungan.” Jurnal Bisnis dan Kewirausahaan. Politeknik Negeri Bali. Bali. Vol. 7. No. 3.

[8] Rangkuti, F. 2013. SWOT Balanced Scorecard: Teknik Menyusun Strategi Korporat yang Efektif plus Cara Mengelola Kinerja dan Resiko. Jakarta: PT Gramedia Pustaka Utama.

[9] Susetyo, Joko dan Sabakula, A.U.L. 2014. "Pengukuran Kinerja Dengan Menggunakan Balanced Scorecard Dan Integrited Performance Measurement System (IPMS)". Yoyakarta: Institut Sains Dan Tekhnologi AKPRIND.

[10] Yuwono, S., E. Sukarno, M. Ichsan. 2006. Petunjuk Praktis Penyusunan Balanced Scorecard Menuju Organisasi yang Berfokus Pada Strategi. Cetakan Kedua. Jakarta: PT. Gramedia. 